\title{
Analisis Pengaruh Karakteristik Individu, Komunikasi Efektif Dan Iklim Organisasi Terhadap Kinerja Karyawan (Studi Kasus Pada PT. Wismilak Inti Makmur Tbk Surabaya)
}

\author{
Nurul Huda \\ Arief Purwanto \\ nurul.huda.macintosh@gmail.com \\ Program Pascasarjana Universitas Widyagama Malang
}

\begin{abstract}
Abstrak: Penelitian ini bertujuan untuk mengetahui bagaimana pengaruh variabel Karakteristik Individu, Komunikasi Efektif, dan Iklim Organisasi secara simultan dan parsial terhadap Kinerja Karyawan serta melihat sejauh mana ketiga variabel tersebut berpengaruh secara dominan terhadap Kinerja Karyawan PT. Wismilak Inti Makmur Tbk Surabaya. Populasi dalam penelitian ini adalah seluruh karyawan, yang tersebar dalam beberapa bagian.

Penelitian ini menggunakan Analisis Regresi Berganda dalam menganalisa data yang diperoleh dari hasil kuesioner. Hasil penelitian ini menunjukkan bahwa Variabel Karakteristik Individu, Komunikasi Efektif dan Iklim Organisasi berpengaruh secara simultan dan signifikan terhadap Kinerja Karyawan PT. Wimilak Inti Makmur Tbk Surabaya.

Hasil uji secara parsial Variabel Karakteristik Individu, Komunikasi Efektif dan Iklim Organisasi berpengaruh secara parsial dan signifikan terhadap Kinerja Karyawan PT. Wimilak Inti Makmur Tbk Surabaya.

Komunikasi Efektif adalah variabel dominan yang berpengaruh terhadap Kinerja Karyawan PT. Wismilak Inti Makmur Tbk Surabaya.
\end{abstract}

Kata Kunci: Karakteristik Individu, Komunikasi Efektif, Iklim Organisasi, Kinerja

Abstract: This study aims to determine how the influence of variables Individual Characteristics, Communication Effective and Climate Organization simultaneously and partially on Employee Performance and see how far these three variables affect dominantly on Employee Performance PT. Wismilak Inti Makmur Tbk Surabaya. The population in this study is all employees, which are scattered in several parts.

This study uses Multiple Regression Analysis in analyzing data obtained from the questionnaire. The results of this study indicate that Variable Characteristics Individual, Effective Communication and Climate Organization influence simultaneously and significantly to Employee Performance PT. Wimilak Inti Makmur Tbk Surabaya.

Partial test results Variable Individual Characteristics, Effective Communication and Climate Organization influence partially and significantly to Employee Performance PT. Wimilak Inti Makmur Tbk Surabaya.

Effective Communication is the dominant variable that affects Employee Performance PT. Wismilak Inti Makmur Tbk Surabaya.

Keywords: Individual Characteristics, Effective Communication, Organizational Climate, Performance.

Membangun komunikasi dalam pemasaran modern adalah menjadi suatu keharusan untuk menjadi yang terdepan dalam menghadapi persaingan bisnis. Perusahaan tidak 
hanya dituntut untuk memberikan service atau pelayanan yang baik, menciptakan produk yang baik, harga yang menarik, serta menyalurkan produk bagi konsumen yang dituju tapi juga dituntut untuk mampu bersaing dengan perusahaan yang lain. Sumber daya manusia merupakan aset paling penting dalam suatu organisasi serta mempertahankan dan mengembangkan organisasi dalam berbagai tuntutan masyarakat dan jaman. Kinerja sumber daya yang baik merupakan hal penting bagi kelangsungan hidup organisasi. Jika organisasi ingin berkembang dengan pesat, organisasi harus mempunyai sumber daya manusia yang mampu menampilkan kinerja yang baik. Penilaian kinerja sesungguhnya merupakan penilaian atas perilaku manusia dalam melaksanakan peran yang mereka mainkan didalam organisasi karena pada dasarnya organisasi dijalankan oleh manusia.

Kinerja atau performance adalah suatu istilah umum yang digunakan untuk sebagian atau seluruh tindakan atau aktivitas dari suatu organisasi pada suatu periode, sering dengan referensi pada sejumlah standar seperti biaya-biaya masa lalu atau diproyekkan, suatu dasar efisiensi, pertanggungjawaban atau akuntabilitas manajemen dan semacamnya (Aliminsyah dan Padji, 2003). Dalam hal ini kinerja pada PT. Wismilak Inti Makmur Tbk adalah hasil kerja secara kualitas dan kuantitas yang dicapai oleh seorang karyawan dalam melaksanakan tugasnya sesuai dengan tanggung jawab yang diberikan kepadanya, baik dari kemampuan kerjasama, inisiatif, keandalan, kualitas maupun kuantitas. Ukuran kinerja yang dijadikan standart operasional PT. Wismilak Inti Makmur Tbk Surabaya. Teori yang dikemukakan oleh Robbins (1996) bahwa pada hakekatnya penilaian terhadap individu merupakan hasil kerja yang diharapkan berupa suatu kenerja yang optimal dan penilaian kerja mencakup : (1) Kerjasama, (2) Kepemimpinan, (3) Kualitas pekerjaan, (4) Kemampuan teknis, (5) Inisiatif, (6) Semangat, (7) Daya tahan, (8) Kuantitas pekerjaan.

Penelitian ini mengkaji mengenai : "Analisis Pengaruh Karakteristik Individu, Kumunikasi Efektif dan Iklim Organisasi terhadap Kinerja Karyawan". (Studi Kasus Pada PT. Wismilak Inti Makmur Tbk Surabaya). Diharapkan nantinya hasil penelitian ini menjadi pedoman perusahaan untuk mendukung dan memotivasi karyawan didalam meningkatkan kualitas dirinya, menumbuhkan jiwa profesionalisme dan membangun komunikasi yang efektif serta menciptakan ilklim yang kondusip antara sesama karyawan, pimpinan dalam setiap devisi dan para pemegang saham terhadap perusahaan guna meningkatkan kinerjanya.

\section{Rumusan Masalah}

Berdasarkan latar belakang dan pemikiran yang dikemukakan diatas, masalah penelitian ini dirumuskan sebagai berikut :

1. Bagimana pengaruh karakterisik individu, komunikasi efektif, dan iklim organisasi secara simultan terhadap kinerja karyawan PT. Wismilak Inti Makmur Tbk Surabaya?

2. Bagaimana pengaruh karakterisik individu secara parsial terhadap kinerja karyawan PT. Wismilak Inti Makmur Tbk Surabaya?

3. Bagaimana pengaruh komunikasi efektif secara parsial terhadap kinerja karyawan PT. Wismilak Inti Makmur Tbk Surabaya?

4. Bagaimana pengaruh iklim organisasi secara parsial terhadap kinerja karyawan PT. Wismilak Inti Makmur Tbk Surabaya? 
5. Variabel mana yang dominan atau berpengaruh terhadap kinerja karyawan PT. Wismilak Inti Makmur Tbk Surabaya?

\section{Tujuan Penelitian}

1. Untuk mengetahui besarnya pengaruh secara simultan variabel karakteristik individu, komunikasi efektif, dan iklim organisasi terhadap kinerja karyawan PT. Wismilak Inti Makmur Tbk Surabaya.

2. Untuk mengetahui besarnya pengaruh secara parsial variabel karakteristik individu terhadap kinerja karyawan PT. Wismilak Inti Makmur Tbk Surabaya.

3. Untuk mengetahui besarnya pengaruh secara parsial variabel komunikasi efektif terhadap kinerja karyawan PT. Wismilak Inti Makmur Tbk Surabaya.

4. Untuk mengetahui besarnya pengaruh secara parsial variabel iklim organisasi terhadap kinerja karyawan PT. Wismilak Inti Makmur Tbk Surabaya.

5. Untuk mengetahui pengaruh yang dominan terhadap kinerja karyawan PT. Wismilak Inti Makmur Tbk Surabaya.

\section{Analisis Industri}

Industri rokok merupakan salah satu sekian banyak gambaran mengenai ketatnya persaingan bisnis dibandingkan dengan industri lainnya di Indonesia, meskipun banyaknya aturan-aturan yang sangat ketat dikeluarkan oleh pemerintah bagi produsen rokok seperti aturan yang berkaitan dengan cukai, kadar nikotin dalam suatu rokok, tidak boleh menayangkan iklan rokok, tingginya kesadaran masyarakat terhadap kesehatan, sehingga membuat ruang gerak para produsen rokok dalam industri ini semakin sempit.

PT. Wismilak Inti Makmur Tbk Surabaya adalah holding company PT. Gelora Djaja dan PT. Gawih Jaya. PT. Gelora Djaja (berdiri sejak 1962) adalah produsen kretek premium merek Galan, Wismilak serta Diplomat. Adapun distribusi produk Wismilak ditangani oleh PT. Gawih Jaya, sejak tahun 1983 dan menjangkau seluruh nusantara, lewat kantor perwakilaan, grosir, retailer, dan para pedagang kretek lainnya.

Wismilak merupakan industri rokok terkemuka Indonesia yang menghsilkan sekitar tiga milyar batang sigaret kretek tangan, sigaret kretek mesin dan cerutu. Didirikan pada tahun 1962, saat ini memiliki 18 kantor cabang, 4 stock points dan 26 agents yang tersebar di seluruh pulau besar Indonesia. Wismilak meraih sukses degan ekuitas premium, manajemen berpengalaman lebih dari 30 tahun, kapabilitas keuangan yang solid dan tumbuh pesat, serta pasar rokok Indonesia yang menjanjikan.

PT. Wismilak Inti Makmur Tbk merupakan holding company dari PT. Gelora Djaja (produsen) dann PT. Gawih Jaya (distributor). Dengan peralanan usaha selama lebih dari 50 tahun, Wismilak terus berkembang sebagai perusahaan modern dengan terus mengembangkan teknologi, sumber daya manusia dan upaya pemsarannya, guna mempertahankan posisinya sebagai industri terkemuka.

Fakta dilapangan walaupun ruang geraknya semakin sempit namun para produsen rokok tidak kehilangan akal untuk mempertahankan atau menambah konsumen baru, dengan mengadakan suatu kegiatan (events) baik itu dalam bidang olahraga, sosial budaya, musik dan jenis kegiatan lain yang menyedot animo masyarakat untuk melihat mengikuti kegiatan yang dimotori oleh perusahaan rokok tanpa harus melanggar aturanaturan yang dibuat oleh pemerintah. 
Kalau kita melihat Industri rokok di Indonesia saat ini maka hal yang wajar jika persaingan bisnis akan mewarnai industri tersebut baik dalam hal SDM (Sumber Daya Manusia) dimana perusahaan dituntut agar karyawannya memiliki kemampuan dalam pengelolaan manajemen baik soft skill maupun hard skill dalam menghadapi persaingan bisnis, apalagi PT HM Sampoerna Tbk yang merupakan pesaing bisnis mampu menguasai pangsa pasar dan mampu pula mempertahankan posisinya sebagai market leader di Indonesia dengan pangsa pasar sebesar 33,4\% dan penjualan sejumlah 105,5 miliar batang sepanjang tahun 2016. (Sumber: https://swa.co.id/swa/capitalmarket/financial-report/sampoerna-kuasai-pangsa-pasar-334).

\section{Perilaku Individu}

Perilaku adalah sikap dan tindakan atau semua yang dilakukan manusia (Mohyi, 1999). Perilaku individu dalam suatu organisasi adalah sikap dan tindakan (tingkah laku) seorang manusia (individu) dalam organisasi sebagai ungkapan dari kepribadian, persepsi dan sikap jiwanya, yang bisa berpengaruh terhadap prestasi (kinerja) dirinya dan organisasinya. Perilaku seorang pekerja adalah kompleks karena dipengaruhi berbagai variabel lingkungan dan banyak faktor individual, pengalaman dan kejadian. Beberapa variabel individual seperti kecakapan, kepribadian, persepsi dan pengalaman mempengaruhi perilaku (Gibson, Ivancevich, dan Donnelly, 1996).

\section{Karakteristik Individu}

Karakteristik individu terdiri dari kemampuan, persepsi, sikap, pengalaman dan motivasi. Karakteristik individu (Azwar, 2000) meliputi berbagai variabel seperti motif, nilai, sifat kepribadian, sikap yang saling berinteraksi satu sama lain dan berinteraksi dengan lingkungan.

\section{Komunikasi Efektif}

Komunikasi efektif sangat penting pada setiap tingkat di dalam setiap organisasi untuk memastikan bahwa organisasi berfungsi dan mencapai sasarannya secara efektif (Cushway dan Lodge, 1995). Komunikasi efektif berarti bahwa maksud dan tujuan yang terkandung dalam komunikasi disampaikan dengan cara sedemikian rupa sehingga dapat dimengerti sepenuhnya oleh penerima (dikutip Moekijat, 1993). Senada dengan pernyataan Pitfield, komunikasi disebut efektif apabila penerima menginterprestasikan pesan yang diterimanya, sebagaimana dimaksudkan pengirim (Supratiknya, 1995). Komunikasi efektif menurut Yeung, Woolcock dan Sullivan (1998) diartikan sebagai kemampuan menyediakan informasi lisan dan tertulis secara jelas, konsisten dan persuasif. Sedangkan Handoko (1995) menyatakan, efektivitas komunikasi dalam organisasi dipengaruhi oleh beberapa faktor, yaitu :

1. Saluran komunikasi formal; mempengaruhi efektivitas komunikasi dengan dua cara, saluran formal semakin melebar sesuai perkembangan dan pertumbuhan organisasi dan saluran komunikasi formal dapat menghambat aliran informasi antar tingkat organisasi.

2. Struktur organisasi; mempunyai pengaruh yang sama terhadap efektivitas organisasi. Kekuasaan dan status dalam organisasi akan menentukan pihak-pihak yang berkomunikasi dengan seseorang serta isi dan ketepatan komunikasi.

3. Spesialisasi jabatan; akan mempermudah komunikasi dalam kelompok yang berbeda, dimana kelompok kerja yang sama cenderung berkomunikasi dengan istilah, tujuan, tugas, waktu dan gaya yang sama. 
4. Pemilikan informasi; individu memiliki informasi khusus dan pengetahuan mengenai pekerjaannya.

\section{Iklim Organisasi}

Stoner (1996), Iklim organisasi adalah suatu sifat atau ciri-ciri yang relatif tetap pada lingkungan internal organisasi dan yang membedakannya dengan organisasi yang lain. Sedangkan ciri-ciri iklim organisasi tersebut adalah dihasilkan oleh tingkah laku dan kebijaksanaan organisasi tersebut adalah dihasilkan oleh tingkah laku dan kebijaksanaan orgnaisasi, dirasakan oleh anggota organisasi, dapat digunakan untuk menafsirkan organisasi, dan sebagai sumber tekanan untuk mengarahkan aktivitas. Konsep iklim organisasi untuk para pemimpin dan individu dalam organisasi itu ada 3 (tiga) tugas yang mendasar adalah :

1. Tugas dapat diselesaikan dengan lebih baik pada beberapa iklim

2. Pimpinan dapat mempengaruhi iklim organisasi

3. Kecocokan antara individu dengan organisasinya berperan penting dalam prestasi dan kepuasan individu dalam organisasi.

\section{Kinerja Karyawan}

Kinerja atau performance merupakan hasil kerja yang dapat dicapai oleh seseorang atau sekelompok orang dalam suatu organisasi, sesuai dengan wewenang dan tanggung jawab masing-masing, dalam rangka upaya mencapai tujuan organisasi bersangkutan secara legal, tidak melanggar hukum dan sesuai dengan moral maupun etika (Prawirosentoso, 1999). Kinerja individu adalah dasar kinerja organisasi, (Gibson et al., 1996) dan untuk memaksimalkan kinerja masing-masing individu, berhubungan dengan perilaku individu.

Kinerja di sini dilihat sebagai kinerja karyawan yang akan baik bila mempunyai keahlian tinggi, bersedia bekerjakarena digaji atau diberi upah sesuai dengan perjanjian, mempunyai harapan masa depan yang lebih baik. Sehingga kinerja sebagai hasil yang diperoleh karyawan berdasarkan ukuran yang berlaku untuk suatu tugas atau pekerjaan yang dilaksanakan dalam waktu tertentu.

\section{Hasil-hasi Peneliltian Terdahulu}

Ada beberapa tinjauan empiris yang memiliki kaitannya dengan permasalahan penelitian ini. Tinjauan tersebut berupa hasil-hasil penelitian yang telah dilakukan oleh peneliti-peneliti terdahulu yang bertujuan memperjelas dan sebagai referensi dalam penelitian ini.

Endah Setyowati (1997), dengan tesis berjudul " Karakteristik Individu dan Karakteristik Pekerjaan Sebagai Faktor yang Membentuk Komitmen Karyawan pada Organisasi, Pengaruhnya Terhadap Prestasi Kerja ", dengan menguji karakteristik individu terdiri dari usia, pendidikan, pengalaman kerja dan karakteristik pekerjaan terdiri dari keragaman ketrampilan, identitas tugas, arti tugas, otonomi dan umpan balik berpengaruh signifikan dengan kemauan bekerja keras dan kebanggaan karyawan yang merupakan indikator komitmen dan akhirnya berpengaruh terhadap prestasi kerja.

Yaqub (1998), melakukan penelitian dengan judul “ Karakteristik Individu, Karakteristik Pekerjaan dan Karakteristik Organisasi Terhadap Kinerja Karyawan (Studi di Perusahaan Air Minum Kodya TK II Malang) “. Hasilnya bahwa secara bersamasama karakteristik individu (jenis kebutuhan, sikap, minat yang dibawa ke tempat kerja) dan karakteristik pekerjaan (tuntutan kecakapan, identitas tugas, derajat otonomi 
berpengaruh signifikan terhadap kinerja karyawan yang terdiri dari kuantitas pekerjaan, kualitas pekerjaan, ketepatan waktu).

Zaenal Affandy (1998), dalam tesisinya meneliti "Pengaruh Pemberian Motivasi dan Gaya Komunikasi Pemimpin Terhadap Prestasi Kerja Karyawan" dengan menggunakan variabel motivasi kerja dan gaya komunikasi pengaruhnya terhadap prestasi kerja karyawan. Hasilnya menunjukkan bahwa gaya komunikasi berorientasi orang, proses dan tindakan berpengaruh terhadap prestasi kerja karyawan sedangkan yang berorientasi ide tidak berpengaruh.

Hasil-hasil penelitian tersebut di atas dapat disimpulkan bahwa peranan karakteristik individu, komunikasi efektif dan iklim organisasi dalam mencapai tujuan perusahaan sangatlah perlu mendapat perhatian khusus terutama bagian sumber daya manusia. Hal ini mengingat peran tugas utama dari seorang manajer sumber daya manusia untuk mengelola sumber daya manusia yang dimiliki dengan seefektif mungkin, supaya bisa diperoleh suatu satuan sumber daya manusia yang tidak mengecewakan, merasa puas dan sangat memuaskan. Manajemen sumber daya manusia adalah satu bagian dari manajemen yang memfokuskan diri pada sumber daya manusia.

\section{Hipotesis}

1. Ada pengaruh karakteristik individu komunikasi efektif dan iklim organisasi secara simultan terhadap kinerja karyawan PT. Wismilak Inti Makmur Tbk Surabaya.

2. Ada pengaruh karakteristik individu secara parsial terhadap kinerja karyawan PT. Wismilak Inti Makmur Tbk Surabaya.

3. Ada pengaruh komunikasi efektif secara parsial terhadap kinerja karyawan PT. Wismilak Inti Makmur Tbk Surabaya.

4. Ada pengaruh Iklim Organisasi secara parsial terhadap kinerja karyawan PT. Wismilak Inti Makmur Tbk Surabaya.

5. Variabel Komunikasi Efektif mempunyai pengaruh dominan tehadap kinerja karyawan PT. Wismilak Inti Makmur Tbk Surabaya.

\section{METODE}

\section{Rancangan Penelitian}

Rancangan penelitian yang digunakan dalam penelitian ini adalah explanatory research yaitu penelitian yang bertujuan untuk menguji suatu teori atau hipotesis guna memperkuat atau bahkan menolak teori.

\section{Lokasi Penelitian}

Penelitian ini dilakasanakan di bagian operasional PT. Wismilak Inti Makmur Tbk Surabaya.

\section{Poulasi dan Sampel}

Populasi penelitian adalah seluruh karyawan bagian operasional yang tercatat yang jumlahnya sekitar 48 karyawan. Dari jumlah ini diambil sebagai sample adalah seluruh karyawan dari PT. Wismilak Inti Makmur Tbk Surabaya yang berjumlah 48 orang Adapun pengambilan sampel dilakukan adalah dengan teknik sensus. 


\section{Variabel}

Yang menjadi variable penelitian ini adalah karaketeristik individu, komunikasi efektif, iklim organisasi dan kinerja karyawan.

Ke empat variable utama tersebut dicerminkan oleh 36 indikator petanyaan sebagai berikut:

1. Diepnuhinya kebutuhan ekstensi karyawan dalam bekerja

2. Dipenuhi kebutuhan pertumbuhan karyawan ditempat kerja

3. Intrinsik faktor dari individu karyawan merupakan faktor kunci pencapaian

4. Ekstrinsik faktor individu karyawan merupakan faktor penunjang pencapaian kinerja yang optimal

5. Setiap karyawan memiliki kesempatan promosi yang sama

6. Karyawan mendapatkan kesempatan mendapatkan penghargaan

7. Setiap karyawan mendapatkan kesempatan mendapatkan fasilitas dan jaminan sosial

8. Terjadi saling pengertian antar bagian dalam menerima atau memberikan informasi tentang pekerjaan

9. Interaksi dengan karyawan menimbulkan suasana menyenangkan

10. Atasan selalu mengikutsertakan karyawan dalam proses pengambilan keputusan

11. Dalam penyampaian keputusan ke karyawan atasan biasanya menyampaikannya langsung ke karyawan

12. Karyawan akan mendapatkan informasi yang jelas, tegas, lengkap, singkat dan tepat waktu atas pekerjaan yang harus dilaksanakan

13. Karyawan memperhatikan setiap informasi dari atasan/ pimpinan

14. Terjadi perubahan sikap karyawan yang positif akibat terpengaruh komunkasi yang telah berlangsung dengan pimpinan

15. Ketaatan menjalankan tugas sesuai dengan prosedur

16. Ketaatan karyawan tehadap disiplin kerja

17. Karyawan bertanggung jawab menjalankan tugas

18. Karyawan bertanggung jawab atas semua keputusan yang diambil

19. Hubungan sesama karyawan harauslah harmonis

20. Hubungan atasan dan bawahan terjalin dengan baik

21. Dukungan antara teman dan bagian sangat menunjang keberhasilan kinerja yang dicapai

22. Tingkat konflik karyawan yang dapat diselesaikan oleh atasan

23. Tingkat konflik antar teman dan bagian ditekan sekecil mungkin

24. Penyelesaian konflik oleh atasan dengan bijaksana

25. Keterbukaan dalam bekerja sehari-hari

26. Bimbingan atasan dan teman kepada karyawan

27. Inisiatif penyelesaian pekerjaan muncul dari dalam diri karyawan

28. Inisiatif dalam perbaikan dalam memperbaiki kesalahan yang dilakukan

29. Inisiatif usulan dari bawahan kepada atasan

30. Dalam bekerja seorang karyawan pantang menyerah

31. Kreatifitas karyawan sangat dibutuhkan dalam mencapai kinerja yang optimal

32. Melakukan terobosan dalam penyelesaian masalah

33. Prosentasi tingkat kesalahan yang dilakukan karyawan serendah mungkin

34. Keakuratan pekerjaan menjadi syarat mutlak karyawan dalam menyelesaikan pekerjaannya 
35. Pemenuhan target yang telah ditetapkan organisasi

36. Kecepatan karyawan dalam pengerjaan pekerjaan sesuai target yang

\section{Jenis dan Sumber Data}

Data yang digunakan dalam penelitian ini adalah data primer yang diperoleh dari wawancara dan penyebaran kuisioner. Data sekunder dalam penelitian ini diperoleh secara tidak langsung melalui buku bacaan yang terkait dengan variabel yang diteliti, data yang diperoleh dari internet, dan jurnal-jurnal yang ada.

\section{Metode Analisis}

Alat analisis yang digunakan untuk menyelesaikan permasalahan yang ada adalah regresi berganda.

\section{HASIL DAN PEMBAHASAN}

\section{Hasil Anlisis Regresi}

Analisis regresi linier berganda berkaitan dengan studi ketergantungan suatu variabel dependen pada satu atau lebih variabel independen dengan tujuan untuk mengetahui seberapa besar pengaruh variabel independen terhadap variabel dependen. Hasil analisis regresi linear berganda antara variabel independen yaitu karakteristik Individu $\left(\mathrm{X}_{1}\right)$, komunikasi efektif $\left(\mathrm{X}_{2}\right)$, dan iklim orgnisasi $\left(\mathrm{X}_{3}\right)$, serta variabel dependen yaitu kinerja (Y) disajikan pada Tabel 1 berikut:

Tabel 1. Analisis Regresi Berganda

Coefficients $^{\text {a }}$

\begin{tabular}{|c|c|c|c|c|c|c|c|c|}
\hline & \multirow[b]{2}{*}{ Model } & \multicolumn{2}{|c|}{$\begin{array}{l}\text { Unstandardize } \\
\text { d Coefficients }\end{array}$} & \multirow{2}{*}{$\begin{array}{c}\begin{array}{c}\text { Standardized } \\
\text { Coefficients }\end{array} \\
\text { Beta } \\
\end{array}$} & \multirow[b]{2}{*}{$\mathrm{t}$} & \multirow[b]{2}{*}{ Sig. } & \multicolumn{2}{|c|}{$\begin{array}{c}\text { Collinearity } \\
\text { Statistics }\end{array}$} \\
\hline & & $B$ & $\begin{array}{c}\text { Std. } \\
\text { Erro } \\
\text { r }\end{array}$ & & & & Tolerance & VIF \\
\hline \multirow[t]{4}{*}{1.} & $\begin{array}{l}\text { (Constan } \\
\text { t) }\end{array}$ & .814 & .817 & & .997 & $\begin{array}{r}.32 \\
4\end{array}$ & & \\
\hline & $\mathrm{X}_{1}$ & .404 & .126 & .232 & $\begin{array}{r}3.20 \\
2\end{array}$ & $\begin{array}{r}.00 \\
3\end{array}$ & .033 & $\begin{array}{r}29.91 \\
3\end{array}$ \\
\hline & $\mathrm{X}_{2}$ & .913 & .093 & .568 & $\begin{array}{r}9.78 \\
5\end{array}$ & $\begin{array}{r}.00 \\
0\end{array}$ & .052 & $\begin{array}{r}19.20 \\
6\end{array}$ \\
\hline & $X_{3}$ & .259 & .096 & .204 & $\begin{array}{r}2.71 \\
4\end{array}$ & $\begin{array}{r}.00 \\
9\end{array}$ & .031 & $\begin{array}{r}32.18 \\
9\end{array}$ \\
\hline
\end{tabular}

a. Dependent Variable: Y 


\section{Coefficients $^{\mathrm{a}}$}

\begin{tabular}{|c|c|c|c|c|c|c|c|c|}
\hline & \multirow[b]{2}{*}{ Model } & \multicolumn{2}{|c|}{\begin{tabular}{|l|} 
Unstandardize \\
d Coefficients
\end{tabular}} & \multirow{2}{*}{\begin{tabular}{|c|}
$\begin{array}{c}\text { Standardized } \\
\text { Coefficients }\end{array}$ \\
Beta
\end{tabular}} & \multirow[b]{2}{*}{$\mathrm{t}$} & \multirow[b]{2}{*}{ Sig. } & \multicolumn{2}{|c|}{$\begin{array}{c}\text { Collinearity } \\
\text { Statistics }\end{array}$} \\
\hline & & $\mathrm{B}$ & $\begin{array}{c}\text { Std. } \\
\text { Erro } \\
\text { r }\end{array}$ & & & & Tolerance & VIF \\
\hline \multirow[t]{4}{*}{1.} & $\begin{array}{l}\text { (Constan } \\
\text { t) }\end{array}$ & .814 & .817 & & .997 & $\begin{array}{r}.32 \\
4\end{array}$ & & \\
\hline & $\mathrm{X}_{1}$ & .404 & .126 & .232 & $\begin{array}{r}3.20 \\
2 \\
\end{array}$ & $\begin{array}{r}.00 \\
3 \\
\end{array}$ & .033 & $\begin{array}{r}29.91 \\
3 \\
\end{array}$ \\
\hline & $\mathrm{X}_{2}$ & .913 & .093 & .568 & $\begin{array}{r}9.78 \\
5\end{array}$ & $\begin{array}{r}.00 \\
0\end{array}$ & .052 & $\begin{array}{r}19.20 \\
6\end{array}$ \\
\hline & $X_{3}$ & .259 & .096 & .204 & $\begin{array}{r}2.71 \\
4\end{array}$ & $\begin{array}{r}.00 \\
9\end{array}$ & .031 & $\begin{array}{r}32.18 \\
9\end{array}$ \\
\hline & $\begin{array}{l}\mathrm{t} \text { tabel } \\
\text { Multiple } \\
\mathrm{R} \text { Square } \\
\text { Adjusted } \\
\mathrm{F} \\
\text { Signifikan } \\
\mathrm{F} \text { tabel } \\
\text { Signifikan }\end{array}$ & Squa & $\begin{array}{l}=1,68 \\
=0 \\
=0, \\
=0, \\
=18 \\
=0 \\
=2, \\
=5\end{array}$ & $\begin{array}{l}0 \\
996 \\
992 \\
992 \\
382,187 \\
000 \\
82 \\
\%\end{array}$ & & & & \\
\hline
\end{tabular}

Sumber : Data primer - diolah 2017

Berdasarkan koefisien regresi, maka persamaan regresi yang dapat dibentuk adalah:

$$
Y=0,814+0,404 X_{1}+0,913 X_{2}+0,259 X_{3}+e
$$

Dimana :

$\mathrm{Y} \quad=$ Kinerja Karyawan

$\mathrm{X}_{1}=$ Karakteristik Individu

$\mathrm{X}_{2}=$ Komunikasi Efektif

$\mathrm{X}_{3}=$ Iklim Organisasi

Dari tabel diatas dengan koefisien regresi sebesar 0,996 yang berarti terdapat pengaruh yang signifikan dengan nilai determinasi $R$ Square sebesar 0,992 yang berarti kontribusi variabel Karakteristik Individu $\left(\mathrm{X}_{1}\right)$, Komunikasi Efektif $\left(\mathrm{X}_{2}\right)$ dan Iklim Organisasi $\left(\mathrm{X}_{3}\right)$ terhadap Kinerja Karyawan (Y) adalah sebesar 99,2\%, sedangkan sisanya dipengaruhi oleh variabel lain yang tidak diikutkan dalam penelitian ini. Yang artinya secara bersama-sama variabel Karakteristik Individu $\left(\mathrm{X}_{1}\right)$, Komunikasi Efektif $\left(\mathrm{X}_{2}\right)$ dan Iklim Organisasi $\left(\mathrm{X}_{3}\right)$ berpengaruh terhadap Kinerja Karyawan $(\mathrm{Y})$. Dengan demikian hipotesis pertama $\mathrm{H}_{\mathrm{o}}$ ditolak dan $\mathrm{H}_{\mathrm{a}}$ diterima.

a. Koefisien regresi dari konstanta diperoleh nilai sebesar 0,814 dengan tanda positif, angka ini memberikan arti bahwa tanpa adanya kontribusi variabel Karakteristik Individu $\left(\mathrm{X}_{1}\right)$, Komunikasi Efektif $\left(\mathrm{X}_{2}\right)$ dan Iklim Organisasi $\left(\mathrm{X}_{3}\right)$ maka akan menurunkan kinerja karyawan PT. Wismilak Inti Makmur Tbk Surabaya. 
b. Koefisien regresi dari Karakteristik Individu $\left(\mathrm{X}_{1}\right)$, memiliki pengaruh signifikan terhadap kinerja karyawan dengan arah yang positif sebesar 0,404 . Hal ini berarti bahwa, jika Karakteristik Individu $\left(\mathrm{X}_{1}\right)$ semakin baik maka akan diikuti dengan meningkatnya kinerja karyawan PT. Wismilak Inti Makmur Tbk Surabaya.

c. Koefisien regresi dari Komunikasi Efektif $\left(\mathrm{X}_{2}\right)$, memiliki pengaruh signifikan terhadap kinerja karyawan dengan arah yang positif sebesar 0,913 . Hal ini berarti bahwa, jika Komunikasi Efektif $\left(\mathrm{X}_{2}\right)$ semakin baik maka akan diikuti dengan meningkatnya kinerja karyawan PT. Wismilak Inti Makmur Tbk Surabaya.

d. Koefisien regresi dari Iklim Organisasi $\left(\mathrm{X}_{3}\right)$, memiliki pengaruh signifikan terhadap kinerja karyawan dengan arah yang positif sebesar 0,259 . Hal ini berarti bahwa, jika Iklim Organisasi $\left(\mathrm{X}_{3}\right)$ semakin baik maka akan diikuti dengan meningkatnya kinerja karyawan PT. Wismilak Inti Makmur Tbk Surabaya.

\section{Uji t}

Pengujian ini dilakukan untuk mengetahui apakah secara parsial variabel independen berpengaruh signifikan terhadap variabel dependen.

1. Karakteristik Individu $\left(\mathrm{X}_{1}\right)$

Variabel Karakteristik Individu memlilki $t_{\text {hitung }}$ sebesar 3,202 Variabel dengan signifikasi 0,003. Karena $t_{\text {hitung }}>t_{\text {tabel }}(3,202>1,680)$ atau signifikasi $t<5 \%(0,003$ $<0,05)$, maka secara parsial variabel Karakteristik Individu $\left(\mathrm{X}_{1}\right)$ berpengaruh terhadap variabel Kinerja Karyawan PT. Wismilak Inti Makmur Tbk Surabaya.

2. Variabel Komunikasi Efektif $\left(\mathrm{X}_{2}\right)$

Variabel Komunikasi Efektif memlilki $t_{\text {hitung }}$ sebesar 9,785 dengan signifikasi 0,000. Karena $t_{\text {hitung }}>t_{\text {tabel }}(9,785>1,680)$ atau signifikasi $t<5 \%(0,000<0,05)$, maka secara parsial variabel Komunikasi Efektif $\left(\mathrm{X}_{2}\right)$ berpengaruh terhadap variabel Kinerja Karyawan PT. Wismilak Inti Makmur Tbk Surabaya.

3. Variabel Iklim Organisasi $\left(\mathrm{X}_{3}\right)$

Variabel Iklim Organisasi memlilki $t_{\text {hitung }}$ sebesar 2,714 dengan signifikasi 0,009. Karena $t_{\text {hitung }}>t_{\text {tabel }}(2,714>1,680)$ atau signifikasi $t<5 \%(0,009<0,05)$, maka secara parsial variabel Iklim Organisasi $\left(\mathrm{X}_{3}\right)$ berpengaruh terhadap variabel Kinerja Karyawan PT. Wismilak Inti Makmur Tbk Surabaya.

\section{Uji F}

Uji $\mathrm{F}$ dimaksudkan untuk mengetahui pengaruh Karakteristik Individu ( $\left.\mathrm{X}_{1}\right)$, Komunikasi Efektif $\left(\mathrm{X}_{2}\right)$ dan Iklim Organisasi $\left(\mathrm{X}_{3}\right)$ terhadap Kinerja Karyawan $(\mathrm{Y})$ secara simultan. Tabel distribusi $\mathrm{F}$ dicari pada $\alpha=5 \%$, dengan derajat kebebasan (df) df1 atau 4-1 = 3, dan df2 n-k-1 atau 48-3-1 = 44. Hasil pengujian menunjukkan bahwa Fhitung $>F_{\text {tabel }}(18,82>2,82)$ dan signifikasi $(0,000<0,05)$,

maka Ho ditolak dan Ha diterima, artinya Karakteristik Individu $\left(\mathrm{X}_{1}\right)$, Komunikasi Efektif $\left(\mathrm{X}_{2}\right)$ dan Iklim Organisasi $\left(\mathrm{X}_{3}\right)$ terhadap Kinerja Karyawan $(\mathrm{Y})$ secara simultan berpengaruh signifikan terhadap kinerja karyawan PT. Wismilak Inti Makmur Tbk Surabaya.

\section{Pembahasan}


Hasil pengujian koefisien dari analisis regresi linear berganda, menunjukkan Karakteristik Individu, Komunikasi Efektif dan Iklim Organisasi berpengaruh secara parsial dan imultan terhadap kinerja karyawan PT. Wismilan Inti Makmur Tbk Surabaya. Hasil pengujian koefisien dari analisis regresi linear berganda, menunjukkan bahwa Karakteristik Individu, Komunikasi Efektif dan Iklim Organisasi berpengaruh signifikan terhadap kinerja karyawan PT. Wismilak Inti Makmur Tbk Surabaya dengan arah positif. Berdasarkan hasil pengujian tersebut, maka dapat disimpulkan bahwa hipotesis yang menyatakan, "ada pengaruh Karakteristik Individu, Komunikasi Efektif dan Iklim Organisasi terhadap kinerja karyawan PT. Wismilak Inti Makmur Tbk Surabaya" diterima. Hal ini mengindikasikan bahwa jika Karakteristik Individu, Komunikasi Efektif dan Iklim Organisasi, memiliki nilai positif, maka akan memberikan pengaruh dalam meningkatkan kinerja karyawan PT. Wismilak Inti Makmur Tbk Surabaya.

\section{Pengaruh Variabel Karakteristik Individu Terhadap Kinerja Karyawan (Y)}

Karakteristik individu akan memberikan dampak yang positif pada kinerja karyawan sebagai perwujudan atas prestasinya. Semakin tinggi tingkat karakteristik individu dalam bidang tugasnya akan semakin tinggi tingkat kinerja karyawan tersebut. Begitu pula sebaliknya karakteristik individu yang rendah akan berdampak pula penurunan kinerja karyawan yang bersangkutan sehingga karakteristik individu berpengaruh sterhadap kinerja karyawan. Hasil penelitian ini sesuai dengan hasil penelitian yang dilakukan oleh Bambang Sukonto (1999), bahwa faktor karakteristik individu berpengaruh positif dan signifikan terhadap kinerja aparatur kecamatan.

Dari hasil penelitian didapatkan bahwa karakteristik individu di PT. Wismilak Inti Makmur Tbk Surabaya sangat memiliki karakteristik individu yang kuat dan berpengaruh dalam melaksanakan tugasnya ini menunjukkan bahwa secara bersamasama karakteristik individu (jenis kebutuhan, sikap, minat yang dibawa ke tempa kerja) berpengaruh terhadap kinerja karayawan.

\section{Pengaruh Komuniksi Efektif Terhadap Kinerja Karyawan}

Organisasi dapat mencapai tujuannya dengan melakukan kegiatan-kegiatan yang telah direncanakan, dikoordinasi dan dievaluasi dengan melewati proses komunikasi. Mengingat yang melakukan kerja sama dalam organisasi atau perusahaan merupakan sekolompok pelaku yang berupa atasan dan bawahan, juga diantara sesama karyawan untuk mencapai suatu tujuan. Oleh karena itu diperlukan adanya media komunikasi secara efektif, agar masing-masing individu mengetahui segala kewajiban dan tanggung jawab yang diembannya.

Pemahaman atas perilaku individu dalam organisasi menjadi semakin penting sebagai bagian dari kegiatan manajemen. Prestasi individu adalah dasar prestasi organisasi, oleh karena itu pemahaman atas perilaku individu adalah hal yang sangat penting bagi pelaksanaan manejemen yang efektif.

Kerja sama dan interaksi dalam organisasi serta upaya mencapai tujuan organisasi dapat terjalin dan tercapai dengan baik apabila didukung oleh komunikasi, seperti yang dikemukakan dalam literatur dan pendapat beberapa peneliti. Tetapi banyak pula organisasi yang masih kurang peduli dalam memahami masalah komunikasi ini. Didalam melakukan interaksi ini perlu menggunakan komunikasi dan melihat perbedaan individu-individu yang ada dalam suatu organisasi, dimana masing-masing individu memiliki potensi-potensi tersendiri, yang tentunya terkondisi untuk mencapai kepuasan dalam bekerja dan meningkatkan kinerja. Kinerja berkaitan dengan prestasi 
memahami kegiatan yang dilakukan oleh seseorang dalam suatu perusahaan. Selanjutanya Komunikasi efektif dapat tercapai apabila memperhatikan beberapa hal (Mohyi, 1999) yaitu :

1. Komunikasi harus dilandasi rasa saling percaya (pengertian).

2. Komunikasi harus memenuhi syarat jelas, tegas, lengkap, singkat, dan tepat waktu.

3. Komunikasi dapat menggunakan persuasi/faktor sugesti, sehingga dapat merubah sikap, tingkah laku dan perbuatan bawahan.

Dari hasil penelitian didapatkan bahwa komunikasi ektif yang dilakukan di PT. Wismilak Inti Makmur Tbk Surabaya sangat bagus dan berpengaruh dalam melaksanakan tugasnya.

\section{Pengaruh Iklim Organisasi Terhadap Kinerja Karyawan}

Iklim organisasi merupakan faktor-faktor meliputi struktur, responsibility dan warmth dalam melaksanakan pekerjaannya. Dengan kata lain setiap karyawan memerlukan kondisi iklim organisasi yang kondusif dalam melaksanakan pekerjaan yang menjadi bebannya sehari-hari. Kenyataan menunjukkan pula bahwa kegiatan yang tidak didukung iklim organisasi yang kondusif maka akan berpengaruh terhadap kinerja karyawan menjadi tidak efektif dan efisien. Selanjutnya Litwin dan Stringer dalam Davis (1997) menegatakan iiklim organisasi dipengaruhi oleh hampir semua hal yang terjadi di dalam organisasi diataranya struktur organisasi, tanggung jawab, dukungan dari teman kerja dalam menyelesaikan pekerjaan dan konflik yang berpengaruh pada kinerja karyawan. Dengan demikian iklim oraganisasi berpengaruh signifikan terhadap kinerja karyawan.

\section{Pengaruh scara Simultan Karakteristik Individu, Komunikasi Efektif dan Iklim} Organisasi Terhadap Kinerja Karyawan.

Karakteristik individu, komunikasi efektif dan iklim organisasi berpengaruh secara simultan terhadap kinerja karyawan. Sehingga apabila karakteristik individu, komunikasi efektif dan iklim organisasi dilakukan secara bersama-sama maka akan berdampak pengaruhnya terhadap kinerja. Artinya peningkatan karakteristik individu, komunikasi efektif dan iklim organisasi secara bersama-sama akan berdampak pada peningkatan kinerja karyawan dan sebaliknya penurunan karakteristik individu, komunikasi efektif dan iklim organisasi akan berdampak pula pada penurunan kinerja karyawan. Dalam hal meningkatkan hasil kinerjanya sudah barang tentu harus dikembangkan dengan memberikan kesempatan kepada karyawan untuk terus mengembangkan diri atas apa yang telah dilkasanakannya selama ini, dengan mengupayakan karyawan merasa nyaman, senang ditempat bekerja, sehingga pekerjaan yang dilaksanakan akan dapat selesai tepat waktu dan menunjukkan hasil kerja yang memuaskan. Dengan demikian secara simultan dan langsung akan memepengaruhi peningkatan kinerjanya.

\section{Keterbatasan Penelitian}

Penelitian ini masih memiliki keterbatasan serta kekurangan yaitu sebagai berikut: Penelitian ini hanya menggunakan 3 variabel independen untuk mengukur kinerja karyawan di PT. Wismilak Inti Makmur Tbk Surabaya, sedangkan masih ada beberapa variabel lain yaitu seperti budaya organisasi, kepemimpinan, kualitas SDM, disiplin, motivasi, lingkungan kerja dan komitmen yang bisa digunakan untuk mengukur kinerja karyawan di PT. Wismilak Inti Makmur Tbk Surabaya. Jadi di dalam penelitian ini masih membutuhkan informasi tambahan terkait tentang variabel lain yang digunakan 
untuk dapat mengukur kinerja karyawan di PT. Wismilak Inti Makmur Tbk Surabaya. Penelitian ini hanya dilakukan pada karyawan bagian operaasional PT. Wismilak Inti Makmur Tbk Surabaya saja, sehingga hasil penelitian ini tidak dapat diterapkan di perusahaan lain.

\section{SIMPULAN}

Penelitian ini dilakukan untuk mengetahui pengaruh karakteristik inividu, komunikasi efektif dan iklim organisasi, bagi karyawan PT. Wismilak Inti Makmur Tbk Surabaya dalam meningkatkan kinerja karyawan. Dalam penelitian ini variabel bebas yang digunakan adalah variabel karakteristik invidu, variabel komunikasi, dan variabel Iklim organisasi sedangkan variabel terikat yang digunakan adalah kinerja karyawan pada PT. Wismilak Inti Makmur Tbk Surabaya.

Berdasarkan hasil analisis dapat diketahui besarnya kontribusi variabel bebas terhadap variabel terikat, dimana factor yang paling dominan diantara semua variable bebas adalah variabel Komunikasi Efektif. Untuk mengetahui pengaruh secara simultan (bersama-sama) tiap variabel bebas terhadap kinerja karyawan dan hasil analisis menunujukkan bahwa semua variabel bebas mempunyai pengaruh yang signifikan terhadap kinerja karyawan.

Sehingga dapat disimpulkan bahwa pengujian terhadap hipotesis yang menyatakan bahwa adanya pengaruh secara bersama-sama (simultan) variabel bebas terhadap variabel terikat (kinerja karyawan) dapat diterima. Pengaruh secara individu (parsial) variabel bebas (karakteristik individu, komunikasi efektif dan iklim organisasi) berpengaruh terhadap kinerja karyawan. Dari factor yang paling dominan diantara semua variable bebas adalah variabel $\mathrm{X}_{2}$ (Komunikasi Efektif). Dari hasil olah data dengan menggunakan SPSS dapat disimpulkan bahwa semua variabel $\mathrm{X}_{1}$ (Karakteristik Individu), $\mathrm{X}_{2}$ (Komunikasi Efektif) dan $\mathrm{X}_{3}$ (Iklim Organiasi) mempunyai pengaruh yang yang signifikan terhadap kinerja karyawan. Dilihat dari koefisien beta standardized, variabel bebes $\mathrm{X}_{2}$ (Komunikasi Efektif) mempunyai pengaruh yang paling dominan diantara variabel-variabel indikator lainnya.

\section{Saran-saran}

Hasil penelitian menunjukkan bahwa faktor yang paling mempunyai pengaruh bagi kinerja karyawan PT. Wismilik Inti Makmur Tbk Surabaya adalah variabel $\mathrm{X}_{2}$ (Komunikasi Efektif). Untuk mencapai hasil yang lebih baik, penulis dapat memberikan saran-saran sebagai berikut :

1. Tingkat kompetensi komunikasi karyawan harus senantiasa dijaga dan tingkatkan baik antar satu divisi maupun dengan divisi yang lain sehingga komunikasi antar karyawan bisa lebih efektif lagi. Karena komunikasi penting dalam menjalankan fungsi utama di dalam organisasi, kendali (kontrol, pengawasan), motivasi, PT. Wismilak Inti Makmur Tbk Surabaya begitu juga pentingnya memahami kerakteristik individu dan iklim organisasi, pengungkapan emosional dan informasi sehingga semakin meningkatkan kinerja dari karyawan itu sendiri.

2. Untuk mengembangkan dan mengoptimalkan SDM (Sumber Daya Manusia) yang berperan bagi karyawan dalam menciptakan kinerja yang optimal, maka disarankan kepada pihak perusahaan agar memasukkan unsur-unsur karakteristik individu, komunikasi efektif dan iklim organisasi dengan mengadakan program pelatihan dan 
pengembangan SDM (Sumber Daya Manusia) sehingga meningkatkan kinerja karyawan itu sendiri. Diharapkan dapat membangun komunikasi yang efektif dan juga dapat memotivasi kondisi psikologi menjadi pribadi karyawan yang matang. Terwujud dalam bentuk kemampuan merasakan, memahami dan secara efektif menerapkan sumber daya dan kepekaan emosi sebagai sumber energi, informasi koneksi dan pengaruh manusia.

3. Penggunaan variabel bebas lain yang mungkin berpengaruh terhadap kinerja, seperti gaya kepemimpinan, kompensasi, motivasi, budaya organisasi, kecerdasan intelegensi dan lainnya.

4. Pemilihan kriteria sampel perlu diperhatikan secermat mungkin, perlu disesuaikan bentuk kuesioner dengan kriteria sampel yang akan mempengaruhi hasil dari penelitian.

5. Dalam penyebaran kuesioner mungkin dapat dilakukan dengan memilih waktu yang tepat, di saat responden tidak sedang dalam waktu jam kerja yang sibuk yaitu pagi hari. Penyempurnaan kuesioner juga dapat dilakukan dengan lebih memperhatikan kembali kata yang digunakan, sehingga item/pernyataan dapat dengan mudah dimengerti oleh para responden.

6. Penelitian ini dilakukan di industri rokok, diharapkan penelitian selanjutnya dapat dilakukan di perusahaan bidang lainnya seperti manufaktur lain dan jasa lainnya yang telah go public.

7. Untuk lebih menyempurnakan penelitian tentang analisis pengaruh karakteristik individu, komunikasi efektif dan iklim organisasi dalam meningkatkan kinerja karyawan di PT. Wismilik Inti Makmur Tbk Surabaya, disarankan untuk peneliti selanjutnya untuk menambahkan faktor-faktor dan variabel lainnya selain yang telah disertakan pada penelitian ini, dan mungkin juga untuk lebih mengembangkannya lagi.

8. Untuk mengukur tingkat kinerja karyawan di PT. Wismilik Inti Makmur Tbk Surabaya dapat digunakan karakteristik individu, komunikasi efektif dan iklim organisasi, yang dapat dilaksanakan secara bersama-sama dalam upaya meningkatkan kinerja karyawan.

9. Variabel komuniksi efektif yang paling penting untuk dipertahankan dalam rangka meningkatkan kinerja karyawan, karena pengaruhnya paling besar dibandingkan dengan variabel yang lainnya.

10. Variabel karakteristik individu merupakan variabel yang perlu dipertahankan, karena pengaruhnya terhadap kinerja karyawan cukup besar, walaupun masih dibawah variabel komunikasi efektif.

11. Variabel iklim organisasi, adalah variabel yang memerlukan perhatian khusus dari pimpinan atau manajemen, karena pengaruhnya terhadap variabel kinerja karyawan paling sedikit dibandingkan dengan variabel yang lain.

\section{DAFTAR RUJUKAN}

Altman, Rob. (2000). Understanding Organizational Climate: Start Minimizing Your Wokrkforce Problem. Water Engerneering \& Management.

Arikunto, S. (2006). Prosedur Penelitian Suatu Pendekatan Praktik Edisi IV. Jakarta : Rineka Cipta.

Agus. Hardjan M. (2003). Komunikasi Intrapersonal \& Komunikasi Interpersonal. Yogyakarta : Kansius.

Hardjana, Andre. 2000. Audit Komunikasi : Teori dan Praktik. Jakarta : Grasindo. 
Hick. Herbert G and Ray Gullett. C. (1995). Organization : Theory and Behavior. Landon : Mc Graw Hill.

Husein, Umar (2005). Metode Penelitian Untuk Skripsi dan Tesis Bisnis. Jakarta : Salemba Empat.

Indriantoro dan Supomo, (1999). Metodelogi Penelitian Bisnis untuk Akuntansi dan Manajemen. Edisi Pertama. BPFE. Yogyakarta. Yogyakarta.

Industri Rokok di Inonesia (2017). https://swa.co.id/swa/capital-market/financialreport/sampoerna-kuasai-pangsa-pasar-334).

Kincaid, D. Lawrence, and Wilbur Schramm, (1977). Asas-Asas Komunikasi Antar Manusia, (Terjemahan Agus Setiadi), LP3ES Jakarta dan West Communication Institute (EWCI) Hawaii.

Kreitner dan Kinicki. (2005). Perilaku Organisasi. Jakarta. Salemba empat. Schuster (Asia) Pte Ltd.

Mangkunegara, Anwar Prabu (2009). Evaluasi Kinerja SDM. Jakarta : PT Remaja Rosdakarya, Edisi Cetakan Kesembilan.

Mathis Robert L., Jackson John H. 2001. Human Resource Management (Terjemahan) Buku 1, Edisi Kesembilan, Penerbit Salemba Empat, Jakarta.

Muhyi, Ach. (1999). Teori \& Perilaku Organisasi, Penrbit UMM Pres Malang

Moekijat, (1993). Evaluasi Pelatihan Dalam Rangka Peningkatan Produktivitas (Perusahaan). Bandung : Mandar maju.

Muhammad. (2000). Penelitian Pendidikan Prosedur Dan Strategi.Bandung : Angksa.

Purnomosidhi, (1990). Manajemen Sumber Daya Manusia. Yogyakarta : BPFE

Prawirosentoso, Suyadi. (1999). Kebijakan Kinerja Karyawan. Yogyakarta : BPFE.

Robbins, Stephen P, (2006), Perilaku Organisasi, Edisi kesepuluh, PT Indeks Jakarta.

Singarimbun, Masri \& sofyan Effendi. (1995). Metode Penelitian Survei, Edisi Revisi, PT. Pustaka LP3ES, Jakarta.

Schein, Edgar H. (1992). Organizational Culture and Leadership, Third Edition. Jossey-Bass Publishers. San Francisco.

Steers, Richard M. (1985). Efektifitas Organisasi, Cetakan Kedua, Alih Bahasan Magdalena amin, Erlangga, Jakarta.

Stephen P, Robbins, Timothy A. Judge. (2014). Organizational Behavior. Global Edition.

Sudjana. (2002). Teknik Analisis Regresi dan Korelasi bagi Para Peneliti. Penerbit Tarsito, Bandung.

Sugiyono. (2001). Metode Penelitian untuk Bisnis. Jakarta: Erlangga

Stringer, Robert. (2002) Leadership and Organizational Climate. New Jersey : Prentice Hall.

Verdeber, (1978). Pentingnya Communication Skill (Keterampilan Berkomunikasi)

Untuk Keunggulan Kompetitif. Tersedia di :

http://itemputih.wordpress.com/2012/02/13/pentingnya-commnunication-skillketerampilan-berkomunikasi-untukkeunggulan-kompetitif/. Di unduh 26 September 2015

Wismilak, (2017). http://www.wismilak.com 